\title{
Knowledge, Attitude and Practice of Self-Medication among Nursing Students of Nepalgunj Nursing Campus Kohalpur Banke
}

\author{
Dhami DB ${ }^{1}$, Dhakal S²
}

\section{ABSTRACT}

Introduction: Self-medication is widely practiced among the nursing students because of easy availability and accessibility of the drugs. Inappropriate self-medication can leads to increased resistance among pathogens, wastage of resources, can cause serious harm and increase morbidity; which indicates needs of responsible self-medication. Aim: This study was to assess the self-medication knowledge, attitude and practice among nursing students. Methods: This was a questionnaire based descriptive cross sectional study conducted in Nursing students of Nepalgunj Nursing Campus, Kohalpur, on August 2019. Questions related to various aspects of self-medication was used for data collection. Results: Out of 120 students, 102 (85\%) students were found practicing self-medication with reason of no need to visit the doctor for minor illness $78 \%$, for quick relief $75 \%$ and for time saving $50 \%$. Only $15 \%$ not taken self-medication reasoning there was risk of adverse effects $65 \%$ and risk of using wrong drugs $60 \%$. The source of information of the drugs used for self-medication was previous prescription and text book was $50 \%$ and $35 \%$ respectively and the source of the drugs was medical store, $88.2 \%$. Majority of $96 \%$ took for headache followed by fever $83.3 \%$; menstrual symptoms $68.6 \%$; and cough and cold $68.6 \%$ and dirrhoea $64.7 \%$. Most of the students $96 \%$ took analgesics and antipyretics drugs. Conclusion: Our study shows that self-medication is significantly practiced by nursing students. There is need to aware them about advantages and disadvantages of self-medication in order to ensure safety and proper use of drugs.

\section{Keywords: Attitude and Practice, Knowledge, Nursing students, Self-medication}

\section{Authors:}

1. Dr. Dabal Bahadur Dhami

2. Mrs. Sanjeeva Dhakal

${ }^{1}$ Department of Pharmacology, Nepalgunj Medical College, Chisapani, Banke

${ }^{2}$ Department of Nursing, Nepalgunj Nursing Campus, Kohalpur, Banke

\section{Address for Correspondence:}

\author{
Dr. Dabal Bahadur Dhami \\ Department of Pharmacology \\ Nepalgunj Medical College \\ Chisapani, Banke, Nepal \\ Email: drddhami@gmail.com
}

\section{INTRODUCTION}

Self-medication is use of drugs to treat self-diagnosed disorders or symptoms or the intermittent or continued use of a prescribed drug for chronic or recurrent disease or symptoms. ${ }^{1}$ Self-medication practice is a growing concern among nursing students and access to drugs and handling them in their future practice makes nursing students more susceptible to self-medication which can lead to incorrect or delay in diagnosis, increased resistance among pathogens, wastage of resources and leads to serious health hazards such as adverse drug reaction and increase morbidity because of drug interactions. ${ }^{2,3,4,5}$ In this situation, we should educate the students about advantages and disadvantages of selfmedication and about rationale use of drugs to the studetns. ${ }^{6}$ Present study was to assess the self-medication practice and related knowledge and attitude among nursing students of Nepalgunj Nursing Campus.

\section{METHODS}

This descriptive cross-sectional study was conducted in nursing students of Nepalgunj Nursing Campus, Kohalpur, on August 2019, after getting permission from ethical committee of Nepalgunj Medical Campus. A total number of $120 \mathrm{PCL}$ nursing students of first, second and third year were included in the study. Pre-validated questionnaire consisting of twelve closed end questions was used for data collection. The nature of study and the procedure of completing the questionnaire was explained to students. The collected data was entered on Microsoft excel and was summarized as counts and percentages.

\section{RESULTS}

All participated students were female. Mean age \pm standard deviation in years was $18.42 \pm 1.07$; range was from 17 to 22 years. Out of 120 students, 102 (85\%) students were found practicing self-medication and the 18 (15\%) not taken selfmedication. 
The source of information of the drugs used for self-medication was previous prescription 50\%, text book 35\%, advertise $10 \%$ and classroom teaching $5 \%$. In $98(88.2 \%)$ the source of the drugs used for Self-medication was medical store.

\section{Knowledge}

Most common reasons for taking self-medication were that there was no need to visit the doctor for minor illness $78 \%$, for quick relief was $75 \%$ and for time saving $50 \%$. There was ease and convenience in taking self-medication (61\%). (Table I)

\begin{tabular}{|lc|}
\hline \multicolumn{1}{c}{ Reasons } & Percentages of students \\
\hline No need to visit the doctor for minor illness & $78 \%$ \\
\hline Quick relief & $75 \%$ \\
\hline Time saving & $50 \%$ \\
\hline Confidence on your knowledge about medicines & $15 \%$ \\
\hline Economical & $18 \%$ \\
\hline Ease and convenience & $61 \%$ \\
\hline Learning opportunity & $10 \%$ \\
\hline
\end{tabular}

Table I : Student's reasons in favour of self-medication

The most common reasons for not taking Self-medication were that there was risk of adverse effects $65 \%$, risk of using wrong drugs $60 \%$, risk of misdiagnosing $53 \%$ and lack of knowledge about medicines was 35\% (Table II).

\begin{tabular}{|lc|}
\hline \multicolumn{1}{c}{ Reasons } & Percentages of students \\
\hline Lack of knowledge about medicines & $35 \%$ \\
\hline Risk of adverse effects & $65 \%$ \\
\hline Risk of using wrong drugs & $60 \%$ \\
\hline Risk of misdiagnosing & $53 \%$ \\
\hline Risk of drug dependence & $20 \%$ \\
\hline Risk of using drugs wrongly & $30 \%$ \\
\hline
\end{tabular}

Table II : Student's reasons not taking self-medication

\section{Attitude}

In our study we found that out of 120 students $32 \%$ nursing students accepted the fact that they always visited a qualified practitioner whenever they fell ill, while $62 \%$ students said that they sometimes visited and $6 \%$ students visited rarely.

\section{Practice}

Among 102 self-medication practicing students, most of the students, $96 \%$ took self-medication for headache followed by fever, $83.3 \%$; menstrual symptoms $68.6 \%$; and cough and cold $68.6 \%$ and diarrhea $64.7 \%$. (Table III).

$\left.\begin{array}{|lc|}\hline \text { Indications } & \begin{array}{c}\text { Number of students } \\ \text { (Percentages) } \mathbf{n = 1 0 2}\end{array} \\ \hline \text { Headache } & 98 \\ \hline \text { Fever } & (96 \%) \\ \hline \text { Cough, cold, sore throat } & 85 \\ \hline \text { Stomach ache } & (83.3 \%)\end{array}\right)$

Table III : Student's indications for self-medication

Most of the students took analgesics and antipyretics drugs $96 \%$ followed by decongestant $63.7 \%$, antispasmodics by $60 \%$ and lozenges and multi vitamins 44\%. (Table IV).

\begin{tabular}{|c|c|}
\hline Drugs & $\begin{array}{l}\text { Number of students } \\
\text { (Percentages) } n=102\end{array}$ \\
\hline Analgesics/antipyretic & $\begin{array}{c}98 \\
(96 \%)\end{array}$ \\
\hline Antimicrobials & $\begin{array}{c}30 \\
(29.4 \%)\end{array}$ \\
\hline Multivitamins & $\begin{array}{c}45 \\
(44 \%)\end{array}$ \\
\hline Antispasmodics & $\begin{array}{c}60 \\
(58.8 \%)\end{array}$ \\
\hline Decongestants & $\begin{array}{c}65 \\
(63.7 \%)\end{array}$ \\
\hline Lozenges & $\begin{array}{c}45 \\
(44 \%)\end{array}$ \\
\hline
\end{tabular}

Table IV : Drugs used for self-medication

\section{DISCUSSION}

In our study 102 (85\%) students were found practicing selfmedication, which is supported by the studies reported in india $88.24 \%$ by Goel Divya et al $^{7}, 88.5 \%$ by Sankdia RK at al ${ }^{8} 76 \%$ in Karachi by Zafar SN et al ${ }^{9} ; 94.1 \%$ in Slovenia by Klemenc-Ketis $Z$ et al ${ }^{10} ; 76.9 \%$ in Bahrain by James et al. ${ }^{11}$

In our study students gave reasons for taking Self-medication were that there was no need to visit the doctor for minor illness $78 \%$, for quick relief was $75 \%$, ease and convenience $61 \%$ and for time saving $50 \%$ and reasons given by rest of the students for not taking Self-medication were that there was risk of adverse effects $65 \%$, risk of using wrong drugs $60 \%$, risk of misdiagnosing $53 \%$ and lack of knowledge about medicines was $35 \%$. Similar findings were there in the study done by Sankdia RK at al ${ }^{8}$ and by James et al. ${ }^{11}$ 
In our study, we found that source of information of the drugs used for Self-medication was previous prescription $50 \%$ and text book $35 \%$, this may be due to the fact that they had visited the doctor for the same illness previously and do not found it necessary to again visit the doctor for the similar complaints. The source of the drugs used for Self-medication was medical store $88.2 \%$, this may be due to the high tendency of selling and purchasing medicines without the prescription of doctors in developing countries like us. Similar results were found in the study done by Sankdia RK at $\mathrm{al}^{8}$ and by Klemenc ketis et al. ${ }^{10}$

We found that most of the students took analgesics for problem of headache and menstrual symptoms, this may be due to the strain on eyes while studying and lack of sleep and pain during menstrual period respectively for which they had to take analgesics and Significant students also took antipyretic for fever. Similar findings were there in study done by by Goel Divya et $a l^{7}$. Sankdia RK at al ${ }^{8}$, by Zafar et al. ${ }^{9}$, James et al. ${ }^{11}$, Thadani et al. ${ }^{12}$ and Phukan Swopna et al. ${ }^{13}$

\section{LIMITATIONS}

The limitations of this study were small sample size, noncomparison nursing students according to their knowledge level and study year, no appropriate dose, frequency and duration of medication and absence of interventions like hazards of irresponsible self-medication. It will be better if it had been done in large scale populations and Multicentric as well as medical and non-medical students with detail history of drug taken for self-medication with antibiotics.

\section{CONCLUSION}

Our study shows that self-medication is significantly practiced by PCL nursing students. It is due to the lack of awareness about the health hazards and high tendency of selling and purchasing medicines without the prescription of doctors in our country. Access to drugs and handling them in their future practice makes nursing students susceptible to self-medication. Although the practice of self-medication is inevitable, the awareness program should be initiated and curriculum should include for nursing about self-medication and government should strictly prohibit the selling and purchasing medicines without the prescription of doctors.

\section{REFERENCES}

1. World Health Organization: Guidelines for the regulatory assessment of Medicinal Products for use in self-medication 2000. Available at: http://apps. who.int/medicinedocs/pdf/ s2218e/s2218e.pdf. Accessed on 4 March 2017.

2. Hughes $\mathrm{CM}$, McElnay JC, Fleming GF. Benefits and risks of selfmedication. Drug Saf 2001; 24: 1027-1037.
3. Sevdul Donmez, Kivanc Gungo and Pinar Gov. Knowledge, attitude and practice of self-medication with antibiotics among nursing studetns. Int. J. Pharmacol.2017 DOI:10,3923.ijp.2017, ISSN 1811-7775

4. World Health Organization: Report of the WHO Expert Committee on National Drug Policies 1995.

5. Banerjee I, Bhadury T. Self-medication practice among undergraduate medical students in a tertiary care medical college, West Bengal. J Postgrad Med. 2012; 58:127-31.

6. Patil SB, S. H. V, B.V. P, Santosh kumar J, Binjawadgi AS, Kanaki AR. Self-Medication Practice and Perceptions Among Undergraduate Medical Students: A Cross-Sectional Study. Journal of Clinical and Diagnostic Research : JCDR. 2014;8(12).

7. Divya Goel, Sanjay Gupta. Self-medication patterns among nursing students in North India .IOSR Journal of Dental and Medical Sciences (IOSR-JDMS) e-ISSN: 2279-0853, p-ISSN: 22790861. Volume 11, Issue 4 (Nov.- Dec. 2013), PP 14-17

8. Sankdia RK, Agrawal M, Rekha PB, Kothari N. A Questionnaire Based Study Regarding the Knowledge, Attitude and Practice of Self-Medication Among Second Year Undergraduate Medical Students. Int J Pharmacol and Clin Sci.2017;6(1):01 05.

9. Zafar SN, Syed R, Waqar S, Zubairi AJ, Vaqar T, Shaikh M, et al. Selfmedication amongst University Students of Karachi: Prevalence, Knowledge and Attitudes. J Pak Med Assoc. 2008;58(4):214-7.

10. Klemenc-Ketis Z, Hladnik Z, Kersnik J. Self-medication among healthcare and non-healthcare students at University of Ljubljana, Slovenia. Med PrincPract. 2010;19(5):395-401. doi: 10.1159/000316380. Epub 2010 Jul 14. [PubMed: 20639665]

11. James $H$, Handu SS, AI Khaja KA, Otoom S, Sequeria RP.Evaluation of the knowledge, attitude, and practice of selfmedication among first-year medical students.Med Princ Pract. 2006;15(4):270-5. [PubMed: 16763393]

12. Thadani S, Salman MT, Ahmad A. Knowledge, Attitude and Practice of Self-medication Among Second Year Undergraduate Medical Students. J Rational Pharmacother Res. 2013;1(3):131-4.

13. Phukan Swopna, Singha Binita. Knowledge, Attitude and Practice of Self Medication Among Nurses and Midwives of a Tertiary Care Hospital. IJHRMLP, 2016:Vol 02 No 02, Page 63-66, ISSN 2454-5139. 